\title{
Slow-flow-type venous malformation of tongue
}

\author{
Kaushal Mahendra Shah, ${ }^{1}$ Amol Karagir, ${ }^{2}$ Shridevi Adaki ${ }^{2}$
}

${ }^{1}$ Department of Oral Medicine, Diagnosis \& Radiology, Bharati Vidyapeeth Deemed University Dental College, Sangli, Maharashtra, India

${ }^{2}$ Department of Oral Medicine and Radiology, Bharati Vidyapeeth Deemed University Dental College, Sangli, Maharashtra, India

\section{Correspondence to} Dr Kaushal Mahendra Shah, thirty2creations@gmail.com

\section{DESCRIPTION}

Vascular malformations arise as a result of abnormal embryonic development. These malformations are generally subdivided into slow-flow lesions (capillary malformation, lymphatic malformation and venous malformation) and fast-flow lesions (arterial malformations as aneurysm and arteriovenous malformation).

We report a young patient with a large venous malformation (VM) involving the tongue. She came to the outpatient department for routine cleaning of teeth, when we noticed a solitary, large reddish purple-coloured lesion involving the anterior portion of the tongue. The patient gave the history of its presence since birth, associated with no pain and no significant complaints while masticating or swallowing. Patient had noticed no regression in its size. On inspection, the anterior dorsum showed an enlarged mass, most of it showing a normal colour, but enlarged papillae and some dispersed purplish strawberry marks probably of erythema (figure 1). The ventral surface of the tongue showed a large globular submucosal reddish purple mass, involving almost the entire anterior portion of tongue, with a few intense purplish areas (figure 2). Anterior portion showed scalloped margins because of indentations of the teeth. Palpation revealed a soft, painless submucosal mass, which was compressible, non-pulsatile and nontender. Diascopy led to the disappearance of the intense purplish colour. No calcifications or audible bruit was evident.

An ultrasound and Doppler study were done to rule out the involvement of fast-flow lesions.

There are various modalities available to treat VMs, such as using $\mathrm{CO}_{2}$ or $\mathrm{Nd}$ : YAG laser, surgical resection, chemotherapeutic stabilisation of lesions and sclerotherapy.

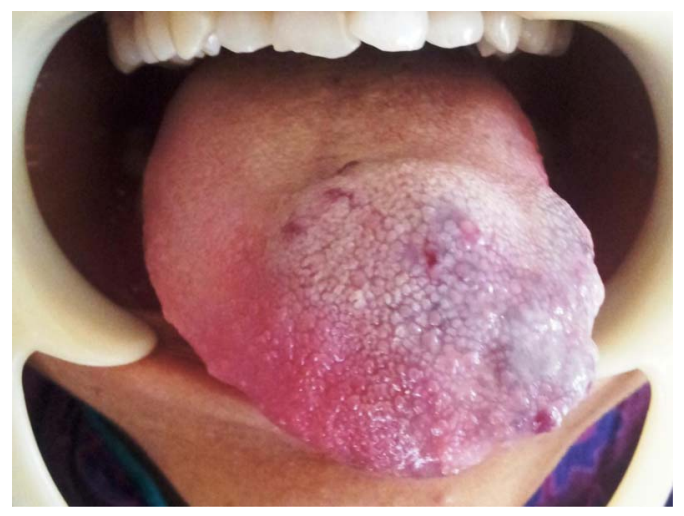

Figure 1 Dorsum of tongue.

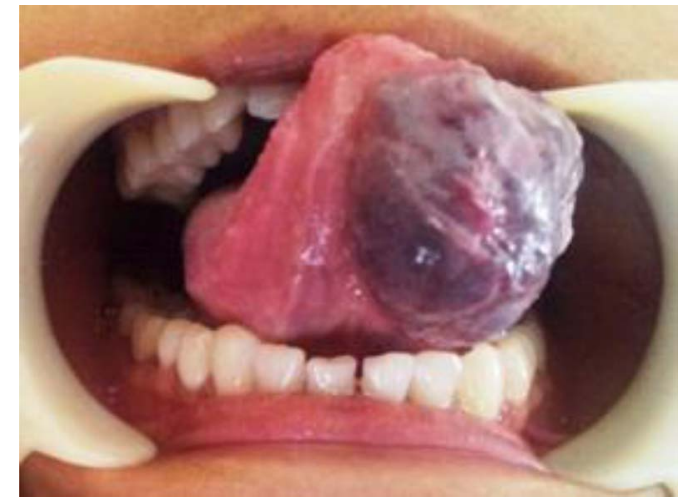

Figure 2 Ventral surface of the tongue.

Our patient was treated with an injection of intralesional sclerosing agent, sodium tetradecyl sulfate (Sotradecol), which has been used with success previously; ${ }^{1}$ as with time, if left untreated, pain and swelling would occur with the formation of phleboliths (calcified thrombi) or small clots, secondary to trauma or venous stasis. ${ }^{2}$

\section{Learning points}

- Cavernous haemangioma (benign tumour/ hamartoma) and venous malformations (vascular malformation) are different entities.

- Venous malformations may be associated with Blue rubber bleb nevus syndrome or Maffucci syndrome (check for other signs and symptoms).

- Venous malformations do not undergo spontaneous resolution, and will require treatment. Sclerotherapy (intralesional injection of a sclerosing agent such as Sotradecol) is the most common form of treatment.

\section{Competing interests None.}

Patient consent Obtained.

Provenance and peer review Not commissioned; externally peer reviewed.

\section{REFERENCES}

1 Siniluoto TM, Svendsen PA, Wikholm GM, et al. Percutaneous sclerotherapy of venous malformations of the head and neck using sodium tetradecyl sulphate (sotradecol). Scand J Plast Reconstr Surg Hand Surg 1997;31:145-50.

2 Berenguer B, Burrows PE, Zurakowski D, et al. Sclerotherapy of craniofacial venous malformations: complications and results. Plast Reconstr Surg 1999;104:1-11. 


\section{Images in...}

Copyright 2013 BMJ Publishing Group. All rights reserved. For permission to reuse any of this content visit http://group.bmj.com/group/rights-licensing/permissions.

BMJ Case Report Fellows may re-use this article for personal use and teaching without any further permission.

Become a Fellow of BMJ Case Reports today and you can:

- Submit as many cases as you like

- Enjoy fast sympathetic peer review and rapid publication of accepted articles

- Access all the published articles

- Re-use any of the published material for personal use and teaching without further permission

For information on Institutional Fellowships contact consortiasales@bmjgroup.com

Visit casereports.bmj.com for more articles like this and to become a Fellow 